\title{
A Study on the Intercultural Communication of Qilu Culture Under the Background of "The Belt and Road"
}

\author{
He DeMin ${ }^{1, a}$ \\ ${ }^{1}$ Media technology of Liaocheng University, Liao Cheng, Shan Ddong, China \\ a7269516@qq..com
}

\begin{abstract}
Now in the new era, cultural exchanges between China and other countries are becoming more and more frequent. Meanwhile, as an important part of Chinese traditional culture, Qilu culture plays an important role in shaping China's international image and building a community of human cultures. This study explores the specific ways implementing the strategy of "Culture Going out" by analyzing the modern connotation of Qilu culture in the new era and its value in cross-cultural communication, combing with the characteristics of film and television culture and its development advantages under the background of "The Belt and Road".
\end{abstract}

Keywords: Qilu Culture, Connotation Value, Communication Strategy, Screen culture, The Belt and Road

\section{INTRODUCTION}

The report of the 19th National Congress of the CPC states: "Culture is the soul of a country and a nation. A prosperous culture means a prosperous country, and a strong culture means a strong nation. Without a high degree of cultural confidence and cultural prosperity, there will be no great rejuvenation of the Chinese nation". ${ }^{[1]} \mathrm{Xi}$ Jinping Thought on Socialism with Chinese Characteristics for a New Era created an important opportunity for our country culture abroad. The community of Shared Future for Mankind built by Xi Jinping in the new era aims to overcome the inherent contradictions and serious drawbacks of globalization and build a world of enduring peace, universal security, common prosperity, openness, inclusiveness, harmony and beauty. At the same time, the cultural community is an indispensable part of the community with a Shared Future for Mankind. As human cultures have their own characteristics, different forms of culture need to be adapted, accepted, inclusive and recognized through dialogue and communication. Therefore, how to effectively eliminate the gap so as to realize the exchange and mutual learning between cultures is the times'proposition before us. In addition, as an important part of China's traditional culture, Qilu culture is not only a brilliant treasure left in the long history of thousands of years, but also plays a pivotal role in China's governance and foreign cultural exchanges. Therefore, the promotion and intercultural communication of Qilu culture play an important role in the enhancement of China's soft power and international status. Under the background of "The Belt and Road", the essence contained in Qilu culture has taken on new significance in modern communication. Therefore, how we should take the express train of "The Belt and Road" to export Qilu culture is the question that we should think calmly and explore seriously in the future.

\section{THE MODERN CONNOTATION VALUE OF QILU CULTURE}

In today's society, inheriting and carrying forward the traditional Chinese culture is the essence of $\mathrm{Xi}$ Jinping Thought on Socialism with Chinese Characteristics for a New Era. It is also an important task in building socialist culture. In 2010, Mr. Huang Huilin put forward the concept of "Third Pole Culture". Its first meaning is that we should systematically screen and summarize Chinese culture itself, take its essence and discard its dross, and carry forward and inherit the most characteristic and representative things, then these contents are the "Pole" of Chinese culture. Therefore, the essence of traditional Chinese culture contained in Qilu culture also belongs to the "Pole". In China, Qilu culture has a long history and its main spirit originated in the period of Spring and Autumn. Under the background of the contention of a hundred schools of thought, the Qi culture and the $\mathrm{Lu}$ culture blended with each other, and Confucianism, which took the doctrine of Confucius and Mencius as its core, emerged. At the same time, Qilu culture and some thoughts of the same period, such as Mohism, Military and Taoism, have influenced the traditional Chinese culture for thousands of years, thus forming the foundation of traditional Chinese culture. In short, Qilu culture, with Confucianism as its core, advocates the concepts of "putting people first, benevolence as the core, virtue as beauty, filial piety as the first, harmony as the most valuable, courtesy as the norm, unity of heaven and man, harmony of Yin and Yang as the highest realm"[2]. In terms of the current Chinese people's ideological and cultural construction as well as national policies and guidelines, these excellent cultural elements and spiritual connotations, which link ancient and modern times, are still playing an important role. 


\subsection{The Spiritual Connotation of Qilu Culture Meets the Requirements of National Development}

In essence, the spiritual connotation of Qilu culture is consistent with the development requirements of China, which is mainly reflected in the following three aspects.

\subsubsection{The Humanistic Thought of Qilu Culture is Consistent with the Essence of the National Governing Policy}

Generally speaking, vigorously propagating and carrying forward the humanistic thought of Qilu culture is conducive to the country's long-term stability and prosperity. In ancient times, Guan zhong, a thinker in the State of Qi in the Spring and Autumn Period, first put forward the concept of people-centered governance. Guan - Ba Yan records: "the premise of being an overlord is the people-oriented. The order makes the country solid, and the chaos makes the country dangerous." This is saying that if you want to achieve hegemony, you should be people-oriented. Then it is recorded in Guanzi Herdsmen that the prosperity of government depends on the obedience of the people. The abandonment of politics is against the will of the people. This tells us that politics flourishes because it conforms to the people, and politics fails because it goes against the people. In Qilu culture, the core of Confucian thought is humanist thought based on "Benevolence". In addition, Mencius' classic judgment that "the people are the most valuable, the state the second, and the monarch the least" (Mencius) is not only highly respected by successive Chinese rulers, but also consistent with the current governing policy of the Communist Party of China which adheres to the principle of people-oriented. In the 19th National Congress of the CPC, it clearly put forward the idea of "thoroughly implementing the peoplecentered development thought" [1]. Therefore, the Communist Party of China has injected the humanistic connotation of Qilu culture into the basic concept of governance in the new era. In addition, since the COVID19 outbreak in 2020, General Secretary Xi Jinping has repeatedly stressed that people's life and health should be put first. All these embody the people-centered humanistic spirit and prove that the spirit is consistent with the humanistic spirit of Qilu culture.

\subsubsection{The Principle of Qilu Culture Promotes the Harmonious Development of Modern Society}

The code of conduct advocated by Qilu culture has become the ideological basis of our current construction of a harmonious society. For example, "Benevolence" advocated by Confucius includes almost all virtues; The "good nature" and "good wisdom" advocated by Mencius are the embodiment of humanism, which still shows the brilliance of human nature ${ }^{[3]}$. It is recorded in the Analects of Confucius: "disciples, filial if they are at home, and obedient to their elders if they go out; widely love the public, but be close to the kind; and if you can spare the strength, learn the literature." It can be seen that, as students and children, we should know how to filial piety parents at home, and listen to the advice of the elders modestly when we are outside; Be prudent and honest in life; Love the people, but keep close to the wise and the virtuous. After you have done all of these, and you still have energy, you can learn six skills, such as ritual, music, archery, royal, book and mathematics. In addition, Confucius placed a person's code of conduct in a very important position. At the same time, he advocated five virtues: "Respect, Generosity, Faithfulness, Sensitivity and Benefit" (The Analects of Confucius). To be specific, respect is to treat the elder with respect and the younger with humility; Generosity is the ability to tolerate others' faults; Faithfulness is to be honest, only in this way can others trust you; Sensitivity is to be diligent and flexible in work; Benefit is to do favor, and to have the spirit of dedication. Therefore, we should carry forward the rules of Qilu culture and constantly improve personal cultivation, so that the country can promote social harmony and stability, which is universal in any era and any country.

\subsubsection{The Principles of Qilu Culture Promote the Harmonious Development of Modern Society}

In the book of Rites, LI Yun records: "When social norms are enforced, the world is shared by all. We will select competent and talented people to serve the people. We must uphold integrity and peace as well as harmony. Therefore, people should not only support their parents and raise their children, but also enable the elderly to live out their days, the middle-aged to serve the society, and the young to grow up smoothly. At the same time, the elderly without a wife, the elderly without a husband, the child of a father who has lost his father in childhood, the elderly without children and the disabled will be provided with support. People abhor the idea of their goods being left on the ground, but not to be enjoyed alone; Abhorrence of those who refuse to do their best in the common labor, always work for self-interest. In this way, there will be no conspiracy, no theft of property, no military disturbances, so there is no need to close the door, this is called the ideal society". In Confucianism, the understanding of "great harmony under heaven" shows the ideal social concept of everyone under heaven for the common". At this time, people live in harmony, live in peace, help each other and do not serve themselves. These virtues bear some resemblance to the ideal of communism. we should think calmly and explore seriously in the future. 


\section{THE COMMUNICATION VALUE OF QILU CULTURE UNDER THE BACKGROUND OF "THE BELT AND ROAD"}

As one of China's top national strategies since the beginning of the new century, the "The Belt and Road" strategy aims to build a community of shared interests, shared future and shared responsibilities based on political mutual trust, economic integration and cultural inclusiveness. At the same time, its influence on the essence of Qilu culture has been reflected in it during the implementation of "The Belt and Road" strategy.

\subsection{The Communication of Qilu Culture and the Implementation of "The Belt and Road"Strategy Complement Each Other}

As is known to all, the development of times requires the exchange and integration of different cultures among countries and nationalities. This is also the inevitable trend of cultural communication and social development, as well as an objective trend of cultural development in today's world. Samuel Huntington, a professor of international politics at Harvard University, pointed out in his article "Clash of Civilizations" that after the end of the political ideological confrontation in the Cold War Era, political and economic conflicts will not be the main conflicts in the future world, but the conflicts of civilizations based on traditional religions will appear continuously [4]. And civilization is the product of positive results and progressive affairs accumulated over a long period of time. Therefore, in today's world, it is very important to protect and disseminate culture. Then the proposal of "The Belt and Road" strategy will promote the external communication and exchange of Chinese culture. At the same time, Qilu culture contains the excellent cultural thoughts of the Chinese nation, and its spiritual connotation also constantly promotes the harmonious development of "The Belt and Road".

\subsection{The "Harmony but not Sameness" in the Qilu culture essence is consistent with the "The Belt and Road"}

We all know that "harmony without uniformity" comes from the statement in The Analects of Confucius that "the superior man is harmonious without uniformity and the inferior man is at variance with each other". It tells the truth of how a gentleman behaves, which reflects the spirit of tolerance and sharing. In essence, it means seeking common ground while reserving differences and making all things harmonious. Chinese Confucian thinkers of all dynasties once regarded harmony as the most basic principle, which was applied in all aspects of "regulating the family, governing the country and bringing peace to the world" (The Book of Rites - The Book of Learning).

After thousands of years of historical changes, "harmony without uniformity"' has not only become the code of conduct for people, but also a basic principle for China's foreign policy. Earlier, regarding the Eastern and Western cultures, The British historian Toynbee pointed out in his article Who Will Inherit the Dominant Position of the West in the World that human beings have mastered the highly technological means of civilization to destroy themselves. But at the same time, it is in the extreme opposition of politics and ideology. The most important spirit that human beings need at present is the essence of Chinese civilization -- harmony ${ }^{[5]}$. Under the current situation, the peaceful thought of seeking common ground while reserving differences and concomitating all nations in Qilu culture has been fully embodied and carried forward in the "The Belt and Road"strategy. At the same time, General Secretary Xi Jinping also pointed out, "The Belt and Road" is open, diversified and win-win. This road is not a private road, but a sunny road where everyone can go forward hand in hand." In addition, "The Belt and Road" initiative calls for a peaceful, stable and win-win development model for Asia and the world at large. It is the cultural concept of "harmony without uniformity" that enables us to build a community with a shared future for mankind. Obviously, this is fundamentally different from the idea and practice of countries that only pursue their own interests while ignoring the interests of other countries, and sometimes resort to violence to solve problems. Therefore, better dissemination of Qilu culture is conducive to better implementation of the "The Belt and Road" strategy, so as to promote world's peace and development. we should think calmly and explore seriously in the future.

\section{HOW TO PROMOTE THE INTERCULTURAL COMMUNICATION OF QILU CULTURE THROUGH FILM AND TELEVISION CULTURE?}

Because film and television can transcend cultural barriers in communication, it has become a powerful tool to promote the communication of foreign cultures. In the era of new media, the role of film and television in cultural communication is becoming more and more obvious. For example, the popularity of "Korean dramas" and "American dramas" has an important enlightening effect on China's cultural communication. Chen Xiaolin, the former deputy director of the International Information Bureau under the Publicity Department of the CPC Central Committee, pointed out at the 2017 Beijing "The Belt and Road" Film and TV Communication Summit that cultural exchanges should be made accessible first. Generally speaking, film and television communication includes two important aspects: one is the production of film and television, the other is the construction and utilization of the communication platform. 


\subsection{The Production of Film and television}

Movies and TV series include documentaries, TV series, movies and Internet shorts, etc. The documentary is one of the indispensable ways to show the traditional culture, because it has the real basic attributes, so it has been popular among the masses of audiences. At the same time, it has strong characteristics of cross-cultural communication, so it is also an important means to carry out cultural exchange. If we want to show Qilu culture, we should play the role of Qilu culture documentary. Because a good documentary can objectively show the spiritual features of Qilu culture from different perspectives, promoting the effective dissemination of its spiritual connotation, thus enhance the audience's value identification and emotional resonance. For example, in the documentary "Family Style of Qilu" produced by Shandong TV station, the values of loyalty, filial piety, benevolence and courtesy of Qilu culture are fully demonstrated. At the same time, it traces the cultural origin of Qilu, discussing the profound influence of "Family Style of Qilu" on the modern family, and the significance of "carrying forward the fine family style" in the new era, and finally wins the unanimous praise from the audience. Of course, in addition to documentaries, TV series, films, internet short films and other films also contain Qilu culture, and their cultural communication ability is equally important. In the intercultural communication of Qilu culture, in order to produce highquality films suitable for foreign audiences, at least the following two aspects should be done.

Firstly, it should be understood by foreign audiences. So far, in the creation of film and television works, the westernization school in the 1860s put forward the idea of "taking Chinese learning as the system and learning Western technology" has a certain reference significance. "Zhong Xue" can be understood as the connotation of Qilu culture in this study, while "Xi Xue" can be understood as the mode of international communication. If we want to introduce Qilu cultural films and TV programs to the world and let more people understand them, we should learn from "Xi Xue". If Qilu culture is to be accepted and recognized by the world, it needs to be expressed internationally in its external communication. Therefore, we should start from the trivial things around Chinese people, and tell the real "Life in China" in a way that foreign people can understand. Since "The Belt and Road" is used in at least 60 countries and more than 40 languages, we need to learn more about their cultures, ways of thinking and habits of appreciation. At the same time, the translation of the text should be done according to local conditions, so that the audience can understand, so as to generate more resonance.

Secondly, let the audience like it. In fact, the external communication of film and television works is to tell "China story" to the world. However, whether the "China story" can be told well depends on whether the audience likes to listen to it and whether they can form a positive interaction with us in the communication. Therefore, the cultural film and television works containing Qilu spirit should focus on exploring Qilu stories with large cultural content, high communication value, strong appeal and popular among audiences of all countries. At the same time, we should combine what we want to say and what foreign audiences want to hear, so as to enhance the affinity of communication. In the documentary "Family Style of Qilu", the drama focuses on "everybody's style" and focuses on the cultural spirit of Qilu culture, such as poetry, etiquette, honesty, filial piety and red culture, which reflects the cultural inheritance from ancient people to modern people. Then, through one story after another, it vividly shows the longitudinal section of qilu culture and good family style. In addition, the TV series Confucius tells the story of a female doctor who studies Confucius thought, showing how Confucius thought is reflected in modern life. Then there is the documentary Film "The Changing China - Life is Hot because of You", which tells the story of the builders of the times through recording the lives of six ordinary workers. The story shows the friendly, hard-working, kind and positive spirit of the Chinese people. Through these representative stories, the essence of Qilu culture is vividly reflected, and the connotation of the times and the majestic power are interpreted. All of these are the top priorities for film and television works to spread Qilu culture.

\subsection{Establishment and Utilization of Communication Platform}

Since the "The Belt and Road" strategy was put forward, the country has attached great importance to the construction of culture and started to actively build a communication platform. By the end of 2016, China had signed intergovernmental agreements on cultural exchanges and cooperated with 64 countries along the "The Belt and Road" route. In addition, China has established various regional dialogue mechanisms with the relevant countries of "The Belt and Road". For example, the China-CEEC Ministers of Culture Cooperation Forum. On the domestic aspect, two platforms have been built. The first one is the Silk Road Film Bridge Project. In March 2014, The State Administration of Press, Publication, Radio, Film and Television (SAPPRFT) launched this project to build a cooperation and exchange platform for four central Asian countries and other countries along the Silk Road with "Internationalization" as the theme and film and television as the media. In this process, a major pattern of regional radio, film and television cooperation has been gradually formed between China and countries along the Silk Road in terms of policy exchange, program trade, and personnel flow. The purpose of this series is to launch a number of "The Belt and Road" themed films, TV dramas and documentaries. The second one is the "The Belt and Road" Media Communication Alliance. In April 2016, the State Council Information 
Office initiated the establishment of 43 organizations, including The China Intercontinental Communication Center and the NATIONAL Geographic Channel. Taking documentary as the core content, the Communication Alliance has built a data resource database platform. At the same time, the documentary resources and broadcast channels of domestic and "The Belt and Road"countries are collected through multimedia means, so as to promote the cooperation in source sharing and program exchange between documentary industry of China and countries along the $\operatorname{road}^{[7]}$. In a word, to spread Qilu culture, we should make full use of these platforms to promote excellent film and television works to the world. At present in China, the number of films and television programs related to Qilu culture is relatively small in international dissemination, and influential works in international projects are even rarer. Therefore, we should pay more attention to improve the quality of works in the future, so as to promote the intercultural communication of Qilu culture.

\section{CONCLUSION}

In general, as the main body of Chinese culture, the rich cultural connotations of Qilu culture, such as benevolent people's love for things, harmony without uniformity, unremitting self-improvement, and striving for success, have been endowed with new modern values under the background of "The Belt and Road" strategy. Moreover, the promotion and inheritance of Qilu culture plays a positive role in promoting the development of Chinese society, and at the same time, promoting Qilu culture to the world can more highlight China's national image and international influence. In the multicultural environment for the development of the world, and on the basis of the spirit of "Benevolence", "Music of Art", "Governance" and "Self-improvement" of Qilu culture, we should strengthen cultural self-confidence, keep pace with the times, innovation, to broaden the channels, so as to dig deeper into which is suitable for human culture ideology of the construction of the community, the humanistic spirit and ethics. Finally, it can extract the cultural essence in line with the development trend of globalization to spread and carry forward, so that Qilu culture shows the elegant demeanor and the permanent charm, thus making due contributions to strengthening China's soft power and international status.

\section{ACKNOWLEDGMENT}

This work was supported by Shandong Social Science Planning Fund Program (20DXWJ01), and liaocheng uiv Foundation of Humanities and Social Sciences (321021921).

\section{REFERENCES}

[1] Xi Jinping. Decisive Victory, Comprehensively Build a Well-off Society, and Win the Great Victory of Socialism with Chinese Characteristics in the New Era-Report at the 19th National Congress of the Communist Party of China [N]. Guangming Daily, 2017-10-28 (04).

[2] Wang Xiuzhi. (2008) Qilu Culture and Shandong People [J]. Dongyue Tribune, 04:1-14

[3] Cheng YuZhen. ( 2000 ) An overview of Chinese culture $[\mathrm{M}]$, Foreign language teaching and Research Press ,Beijing.

[4] Samuel Huntington, Zhou Qi(translator) ( 2013 ). Conflict of Civilizations [M]. Xinhua Publishing House, Beijing

[5] Wang Zhenmin, Yu Yiding.(2009) A Look at SinoAmerican Relationship from Cultural Difference [J]. Journal of Xi' an Jiaotong University (Social Sciences), 02: 91-96

[6] Xi Jinping. Jointly Create Openness, Inclusiveness and Promote Peaceful Development: Speech at the Dinner of the Mayor of the Financial City of London $[\mathrm{N}]$. Guangming Daily, 2015-10-23 (01).

[7] Fu Li "Belt and Road": New Potential for Chinese Film and Television Development [N]. Guangming Daily, 2017-05-03 (12) 